\title{
Proteolysis on Reggianito Argentino Cheeses Manufactured with Natural Whey Cultures and Selected Strains of Lactobacillus helveticus
}

\author{
E. R. Hynes, ${ }^{1}$ C. V. Bergamini, ${ }^{2}$ V. B. Suárez, and C. A. Zalazar ${ }^{1}$ \\ Programa de Lactología Industrial, \\ Facultad de Ingeniería Química \\ (Universidad Nacional del Litoral) \\ Santiago del Estero 2829-S3000AOM Santa Fe, Argentina
}

\section{ABSTRACT}

Reggianito Argentino cheese is traditionally manufactured with whey starter cultures that provide typical and intense flavor but can cause poor quality standardization. In this study, the influence of natural and selected starters on Reggianito Argentino cheese proteolysis was investigated. Cheeses were manufactured with three strains of Lactobacillus helveticus (SF133, SF138 and SF209) cultured individually in sterile whey and used as single or mixed starters. Control cheeses were made with natural whey starter culture. Cheeses were analyzed to determine gross composition, as well as total thermophilic lactic flora. Proteolysis was assessed by $\mathrm{N}$ fractions, electrophoresis and liquid chromatography. Gross composition of the cheeses did not significantly differ, while viable starter cell counts were lower for cheeses made with strain SF209 alone or combined with other strains. Soluble $\mathrm{N}$ at $\mathrm{pH} 4.6$ was the same for cheeses made with natural or selected starters, but soluble $\mathrm{N}$ in $12 \%$ trichloroacetic acid and $2.5 \%$ phosphotungstic acid was significantly higher in cheeses made with starters containing strain SF209. Nitrogen fractions results indicated that natural whey starter cultures could be replaced by several starters composed of the selected strains without significant changes to proteolysis patterns. Starter cultures prepared only with SF209 or with the three selected L. helveticus strains produced cheese products with significantly more proteolysis than control cheeses. Chromatographic profiles analyzed by principal components showed that three main peaks on chromatograms, presumptively identified as Tyr, Phe, and Trp, explained most of variability. Principal component scores indi-

Received February 17, 2003.

Accepted July 7, 2003.

Corresponding Author: E. R. Hynes; e-mail: ehynes@fiqus.unl. edu.ar.

${ }^{1}$ Researcher from CONICET (Consejo Nacional de Investigaciones Científicas y Técnicas), Argentina.

${ }^{2}$ Doctoral fellow from CONICET, Argentina. cated that cheese samples were grouped by ripening time, which was confirmed by linear discriminant analysis. On the contrary, samples did not cluster by Lactobacillus strain or type of starter.

(Key words: Reggianito Argentino cheese, cheese ripening, proteolysis, peptide profiling)

Abbreviation key: LDA = linear discriminant analysis, PCA = principal component analysis, PTA = phosphotungstic acid, RAPD = randomly amplified polymorphic dna-polymerase chain reaction, RP-HPLC $=$ reverse phase high performance liquid chromatography, $\mathbf{S N}=$ soluble nitrogen, $\mathbf{T F A}=$ trifluoroacetic acid .

\section{INTRODUCTION}

The role of lactic starter cultures bacteria is the metabolism of lactose to lactic acid, a process that improves milk clotting, whey syneresis, and protects the final product against bacterial contamination. Starter cultures also play a major role during ripening, because they contribute to the aroma and flavor of the cheese due to proteolysis, carbohydrate metabolism, and to a lesser degree lipolysis (Crow et al., 1993; Fox and McSweeney 1996; Choisy et al., 1997). Among these main biochemical transformations, proteolysis is the major event during the ripening of most cheeses as it affects texture and contributes to flavor by providing some taste and aroma compounds and most of their precursors (McSweeney and Sousa, 2000).

Reggianito Argentino cheese is the most popular Argentinean hard cheese (Centro de la Industria Lechera, 2001). It was derived from Italian cheeses such as Parmiggiano Regiano and Grana Padano in late 19th and early 20 th centuries by Italian immigrants (Zalazar et al., 1999). The manufacturing stages were then adapted to Argentinean raw materials and environmental characteristics to make a distinct product. To prepare the starter culture for Reggianito cheese, a predetermined volume of whey is recovered directly from the cheese vat at $\sim 52^{\circ} \mathrm{C}$ after the cooking step and held for $24 \mathrm{~h}$ as the temperature decreases $\left(\sim 52^{\circ} \mathrm{C}\right.$ to $\sim 35^{\circ} \mathrm{C}$ ) (Gallino, 
1994; Zalazar et al., 1999). The microbiological composition of such natural starter cultures may be easily affected by either the environmental conditions or cheesemaking technology (Giraffa et al., 1998). As a consequence of multiple equilibriums and natural selection, a complex starter is obtained after $24 \mathrm{~h}(\mathrm{pH} \sim 3)$. In this way, the supply of whey starter cultures is readily available from the whey of the previous cheesemaking day. One of the characteristics of Reggianito Argentino that distinguishes it from other hard cheeses like Parmesan is the microflora of Argentinean whey cultures. Whey cultures from our region (Santa Fe, Argentina) are composed of $\sim 66 \%$ Lactobacillus helveticus strains and $\sim 33 \%$ of Lactobacillus delbrueckii subsp. lactis strains (Reinheimer et al., 1996), while the Italian cultures showed a somewhat different microbial composition: the most common species were $L$. helveticus and L. delbrueckii subsp. bulgaricus, sometimes accompanied by L. delbrueckii subsp. lactis, Lactobacillus casei subsp. casei, Lactobacillus fermentum, and Streptococcus thermophilus (Reinheimer et al., 1995).

Among the advantages of using natural whey starter cultures are the contribution to final product typical flavor and aroma, attributed to the complex microflora, and the resistance to phage attack due to the multi strain culture (Bottazzi et al., 1992; Giraffa et al., 1997). On the other hand, poor quality standardization and eventual contamination mainly with yeasts, has been pointed as disadvantages in Argentinean whey cultures (Reinheimer et al., 1996). Thus, the objective of many studies has been to find cultures that gather the advantages of natural whey cultures and a greater control of the cheese-making and ripening processes, provided by selected starters (Bosi et al., 1991; Paleari et al., 1996; Bottazzi et al., 1999).

In the present work, we studied proteolysis during ripening of Reggianito cheeses manufactured either with natural whey starter culture or with single and mixed cultures of $L$. helveticus selected strains. Cheesemaking experiments, microbiological analysis, and proteolysis assessment were performed to determine whether natural cultures could be replaced by selected starters without significant changes in Reggianito ripening patterns.

\section{MATERIALS AND METHODS}

\section{Starter Cultures}

The L. helveticus strains used in the present study were isolated and studied in previous works. Isolates, obtained from natural whey cultures used in dairy industry, were screened for technological parameters such as acidifying and proteolytic activities, $\mathrm{NaCl}$ sensitivity, and resistance to phages (Reinheimer et al.,
1995, 1996; Quiberoni et al.,1997). The most suitable strains from a technological point of view, identified as L. helveticus SF133, SF138, and SF209, were chosen for the present study. These strains were also characterized by randomly amplified polymorphic DNA-PCR (RAPD-PCR) (Quiberoni et al., 1998). The single strains were cultured in sterilized $\left(110^{\circ} \mathrm{C} ; 10 \mathrm{~min}\right)$, reconstituted ( $10 \% \mathrm{wt} / \mathrm{vol})$, low-heat skim milk powder at $45^{\circ} \mathrm{C}$ for $24 \mathrm{~h}$.

Whey samples were taken from a nearby Reggianito Argentino dairy plant after the cooking step and immediately carried to our laboratory under refrigerated conditions $\left(4^{\circ} \mathrm{C}\right)$. Once in the laboratory, whey $\mathrm{pH}$ was adjusted to 6.3 with $40 \% \mathrm{NaOH}$, wt/vol, under controlled microbiological conditions and divided into two fractions. One of the fractions was incubated for $24 \mathrm{~h}$ at $45^{\circ} \mathrm{C}$ in order to obtain control natural whey starter, in which $\mathrm{pH}$ reached $3.15 \pm 0.05$. The remaining fraction was heated for $5 \mathrm{~min}$ at $85^{\circ} \mathrm{C}$ in order to destroy all vegetative cells. After cooling to $45^{\circ} \mathrm{C}$, it was inoculated ( $2 \% \mathrm{vol} / \mathrm{vol}$ ) with $L$. helveticus SF133, SF138, or SF209 milk cultures and incubated as the control. These whey cultures constituted the single strain starters used in the study; they reached a $\mathrm{pH}$ value slightly higher than the control: $3.25 \pm 0.05$. Two or three strain starters were obtained by mixing equivalent amounts of single strain cultures immediately before inoculation to cheese milk. Lactobacilli population was $10^{8} \mathrm{cfu}$ per milliliter both in single cultures and control whey culture (Candioti et al., 2002).

\section{Cheese-Making}

Control cheeses were made with natural whey starter culture, while experimental cheeses were prepared with single strain starter cultures (SF133, SF138, and SF209), two-strain starter cultures (SF133 + SF138, SF138 + SF209, and SF209 + SF133), and three strain starter culture (SF133 + SF138 + SF209). Three replicates were made for each type of cheese, which gave a total of 24 cheeses. Two cheeses were manufactured each cheese-making day in two parallel vats of $85 \mathrm{~L}$. The order in which cheeses were manufactured was selected at random.

Cheese-making was carried out following the standard Reggianito cheese technology (Gallino, 1994). Raw milk was supplied by Milkaut Coop. Ltda. (Colonia Nueva, Santa Fe, Argentina). Fat content was standardized to $2.50 \%$ by centrifugation (Alfa Laval Separator Co., Tumba, Sweden) and milk was batch pasteurized at $65^{\circ} \mathrm{C}$ for $20 \mathrm{~min}$. After cooling to $33^{\circ} \mathrm{C}, \mathrm{CaCl}_{2}$ was added to a final concentration of $0.02 \%$, wt/vol. 25 to $30 \mathrm{ml} / \mathrm{L}$ of whey starter culture (pH 3.15 to 3.25 ) was added, decreasing milk $\mathrm{pH}$ from approximately 6.70 to 
6.50. After stirring, $0.29 \mathrm{ml} / \mathrm{L}$ of milk of adult bovine coagulant was added (230 International Milk Clotting Units per ml; Naturen, Chr. Hansen, Quilmes, Argentina). After 18 to $20 \mathrm{~min}$, when the curd reached the proper strength, it was cut to the adequate grain size (approximately half a rice grain) with a cheese harp whose wires were spaced at $10 \mathrm{~mm}$. The mixture of the curd particles and whey was gently stirred and heated at $0.5^{\circ} \mathrm{C} / \mathrm{min}$ until it reached $44^{\circ} \mathrm{C}$ in order to reduce moisture in curd grains. The mixture was then more rapidly heated to $51^{\circ} \mathrm{C}\left(1^{\circ} \mathrm{C} / \mathrm{min}\right)$, stopping the stirring at this point. The curd was separated, put into cylindrical moulds (diameter $26 \mathrm{~cm}$, height $15 \mathrm{~cm}$ ), and pressed during $24 \mathrm{~h}$ at decreasing temperature (from $\sim 52^{\circ} \mathrm{C}$ to room temperature). After that, cheeses were salted in $20 \%$ (wt/vol), $\mathrm{pH} 5.4$ brine at $12^{\circ} \mathrm{C}$ for $6 \mathrm{~d}$. During this time the cheese was inverted every other day. The obtained 7-kg cheeses were dried and ripened at $12^{\circ} \mathrm{C}$ and $80 \%$ relative humidity for $6 \mathrm{mo}$, the minimum time required by Argentinean legislation for Reggianito Argentino cheese (Código Alimentario Argentino, 1999).

\section{Gross Composition of Cheeses}

Dry matter and protein content were analyzed according to IDF standards (IDF, 1962; IDF, 1993), and fat and $\mathrm{pH}$ by American Public Health Association methods (Bradley et al., 1993) on 180-d-old cheeses.

\section{Microbiology}

The population of total thermophilic lactic flora present in cheeses after 0 (fresh curd), 1 (curd after pressing), 90, and $180 \mathrm{~d}$ of ripening was determined by plating sample dilutions on skim milk agar and counting plate colonies after $48 \mathrm{~h}$ of incubation at $37^{\circ} \mathrm{C}$ according to American Public Health Association standards (Frank et al., 1993). Coliforms were enumerated on bile red violet agar, and the plates were incubated for $24 \mathrm{~h}$ at $30^{\circ} \mathrm{C}$ (Christen et al., 1993). Fresh whey was also analyzed by a modified Weinzirl method (Annibaldi, 1969) to determine sporulated anaerobic organisms. Mold and yeasts were determined according to American Public Health Association (Frank et al., 1993) on the starter cultures.

\section{Proteolysis Assessment}

Proteolysis was assessed on 0-, 90- and 180-d-old cheeses, by determination of soluble $\mathrm{N}(\mathbf{S N})$ at $\mathrm{pH} 4.6$, in TCA $12 \%$ and in phosphotungstic acid (PTA) $2.5 \%$. Electrophoresis and reverse phase liquid chromatography (PR-HPLC) were also performed.

Soluble nitrogen. Cheese samples were treated to obtain crude citrate extract and soluble fractions at $\mathrm{pH}$
4.6, in TCA $12 \%$ and PTA $2.5 \%$, according to Hynes et al. (2001). The crude cheese extract was obtained by adding $20 \mathrm{ml}$ of sodium citrate $0.5 \mathrm{M}$ to $10 \mathrm{~g}$ of cheese and grounding to homogeneity using a pestle. Deionized water was added to $\sim 90 \mathrm{ml}$, and the $\mathrm{pH}$ was adjusted to 4.6. After centrifugation $(3000 \times g / 15 \mathrm{~min})$, the soluble fraction volume was adjusted to $100 \mathrm{ml}$. The TCA $12 \%$ and PTA 2.5\% soluble fractions were obtained from 4.6 soluble fraction according to Gripon et al. (1975). The $\mathrm{N}$ content was determined in duplicate by the macroKjeldahl method according to the IDF method (1993).

Electrophoresis. The insoluble residue at $\mathrm{pH} 4.6$ was analyzed by Urea-PAGE in a Mini-Protean II cube (BioRad Laboratories, CA) by the Andrews (1983) method, with a concentration of acrylamide of $7.5 \%$ (Hynes et al., 1999). Proteins were stained by Coomasie blue G-250. Samples of cheese casein were prepared by precipitation at $\mathrm{pH} 4.6$ and purified.

Reverse phase-high performance liquid chromatography (RP-HPLC). The HPLC equipment consisted of a quaternary pump, an online degasser, and UV/VIS detector, all Series 200, purchased from Perkin Elmer (Perkin Elmer, Norwalk, CT). An interface module connected to a computer was used for acquisition of chromatographic data with the software Turbochrom (Perkin Elmer). A 250- × 4.6-mm Aquapore OD-300 $\mathrm{C} 18,5 \mathrm{~nm}-300 \mathrm{~A}^{\circ}$ analytical column was used (Perkin Elmer). Water-soluble extracts of the cheeses were obtained by blending $5 \mathrm{~g}$ of cheese and $15 \mathrm{ml}$ of distilled water with mortar and pestle, then warmed up to $40^{\circ} \mathrm{C}$ and maintained for $1 \mathrm{~h}$. The suspension was centrifuged at $3000 \times g$ and filtered through fast flow filter paper. The filtered solution was adjusted to a final volume of 25 ml. Samples were filtered through $0.45 \mu \mathrm{m}$ membranes (Millex, Millipore, São Paulo, Brazil), and $20 \mu \mathrm{l}$ was injected into the HPLC chromatograph. Detection was performed at $214 \mathrm{~nm}$, and column temperature was $40^{\circ} \mathrm{C}$. The gradient, starting from $100 \%$ of solvent A $\left(\mathrm{H}_{2} \mathrm{O}\right.$-trifluoroacetic acid (TFA), 1000:1.1, vol/vol) and 0\% of solvent B (Acetonitrile- $\mathrm{H}_{2} \mathrm{O}-\mathrm{TFA}$ 600:400:1, vol/ $\mathrm{vol} / \mathrm{vol}$ ), was generated $10 \mathrm{~min}$ after injection. The proportion of solvent B was increased by $1 \% / \mathrm{min}$ (80 min), $20 \% / \mathrm{min}$ ( $1 \mathrm{~min}$ ), $0 \% / \mathrm{min}$ (4 min), and then returned to starting conditions, which took $1 \mathrm{~min}$. These last setting conditions were maintained for $10 \mathrm{~min}$.

\section{Statistics}

Nitrogen fraction data were processed by one-way ANOVA with Statistix 7 (Analytical Software, Tallahasse, FL). When differences were found, means were compared by the LSD using the same tool.

Principal component analysis (PCA) and linear discriminant analysis (LDA) were applied to data obtained 


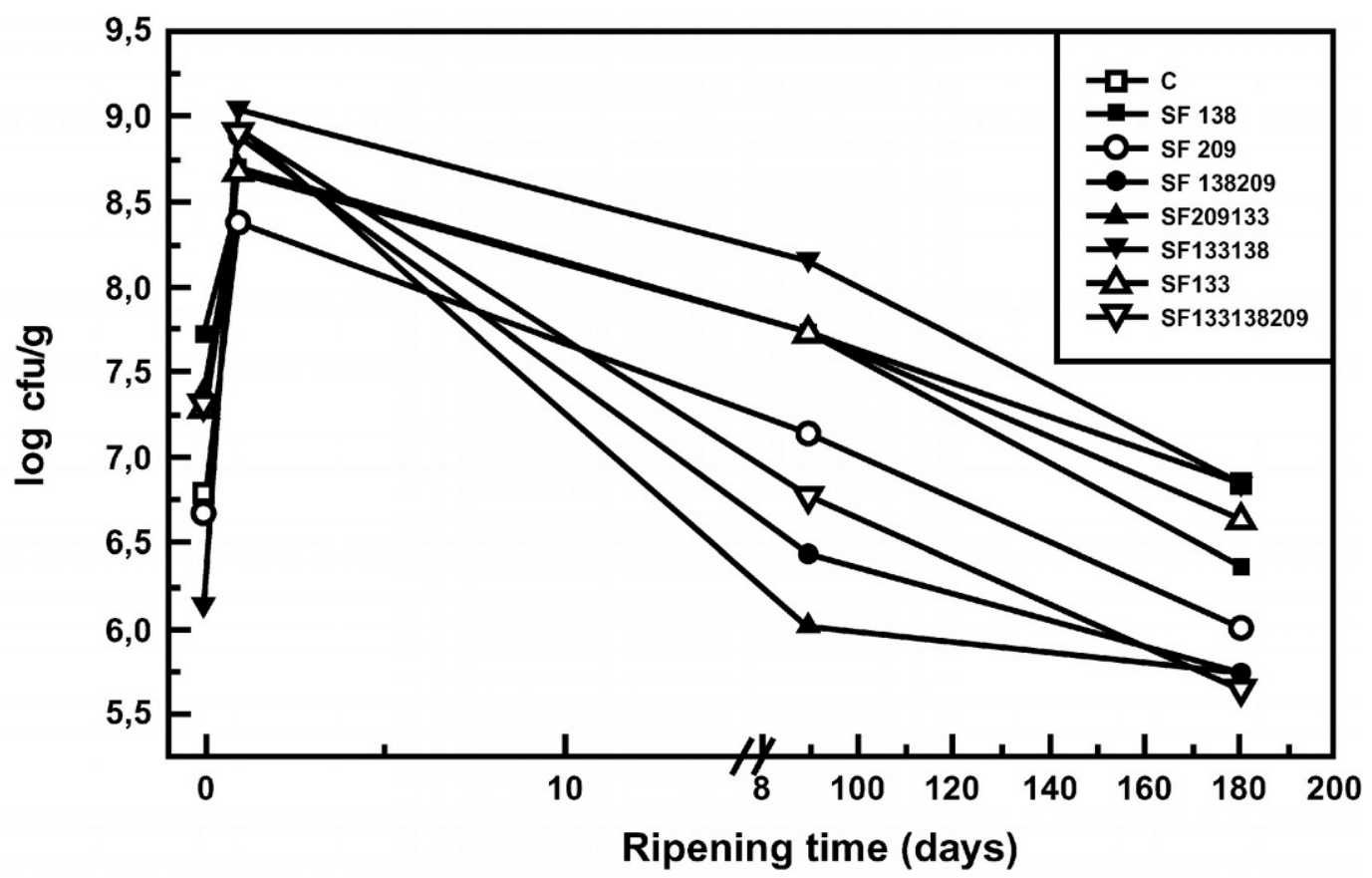

Figure 1. Evolution of lactobacilli population during ripening of Reggianito cheeses. C: control: lactobacilli plate counts on cheese prepared with natural whey starter. SF133, SF138, and SF209: lactobacilli plate counts on cheeses prepared with single strain cultures of Lactobacillus helveticus; SF 133-138, SF 138-209, and SF 209-133 cheeses with two strain cultures; and SF133-138-209: cheeses with three strain starter culture. Values are the means for three replicate cheeses.

from RP-HPLC profiles. All multivariate techniques were performed with Statgraphic plus 3.0 (Rockville, MD).

\section{RESULTS}

Gross composition of cheeses did not differ $(P>0.05)$ among starters. Dry matter, fat, protein, and $\mathrm{pH}$ were $62.84 \pm 1.17 \%, 23.96 \pm 1.28 \%, 28.95 \pm 0.55 \%$, and 5.16 \pm 0.01 , respectively. These are considered appropriate values for Reggianito cheese according to the Argentinean codex (Código Alimentario Argentino, 1999).

Figure 1 shows changes on lactic acid bacteria counts during ripening. Starter number was between $10^{6}$ and $10^{7} \mathrm{cfu} / \mathrm{g}$ in curd before molding, in cheeses made with natural culture and L. helveticus strains SF133, SF138, and SF209. The other cultures provided an initial cell count of $10^{7}$ to $10^{8} \mathrm{cfu} / \mathrm{g}$. Starter cell numbers reached a maximum of $10^{8}$ to $10^{9} \mathrm{cfu} / \mathrm{g}$ at $24 \mathrm{~h}$ in all cheeses, and then decreased by one or two log orders during ripening. Cheeses prepared with the strain SF209 showed the lowest final counts, about $10^{6} \mathrm{cfu} / \mathrm{g}$. That was verified in cheeses made with the single-strain culture, and manufactured with two and three strain combinations containing SF209, i.e.: SF133-SF209, SF138SF209, and SF133-SF138-SF209.
Coliform bacteria counts were $<10^{2} \mathrm{cfu} / \mathrm{g}$ for control and experimental 180-d-old cheeses. Sporulated anaerobic organisms were not detectable by the Weinzirl method in all fresh whey samples. After incubation, counts of yeasts and moulds on natural whey cultures were $\sim 10^{4} \mathrm{cfu} / \mathrm{ml}$. In contrast, yeasts and molds did not occur in selected strain cultures, because all vegetative cells were destroyed before $L$. helveticus inoculation, as was verified (data not shown).

Soluble $\mathrm{N}$ level at $\mathrm{pH} 4.6$, in TCA $12 \%$ and in PTA $2.5 \%$, for $0-, 90-$, and $180-\mathrm{d}$-old cheeses, is represented in Table 1. The content of SN at $\mathrm{pH} 4.6(\mathrm{pH} 4.6 \mathrm{SN})$ did not differ $(P>0.05)$ between control and experimental cheeses during ripening. Significant differences in SN at $\mathrm{pH} 4.6$ were not expected, as this fraction represents mainly primary proteolysis, due especially to indigenous milk enzymes and possibly to residual or reactivated chymosin in cooked cheeses (Delacroix et al., 1992).

Soluble N level in TCA $12 \%$ did not show significant differences among cheeses manufactured with diverse starter cultures either at 0 or $90 \mathrm{~d}$ of ripening. However, highly significant differences $(P<0.001)$ were found among 180-d-old cheeses. The highest amount of TCA $12 \%$ SN was detected in cheeses manufactured with $L$. helveticus SF209 culture and the lowest in those made 
Table 1. Nitrogen content in cheese soluble fractions at $\mathrm{pH} 4.6$ (pH $4.6 \mathrm{SN}$ ), in tricholoracetic acid $12 \%$ (SN TCA) and phosphotungstic acid 2.5\% (SN PTA), expressed as the percentage of total N, at 0, 90, and $180 \mathrm{~d}$ of ripening. C: cheeses with natural whey starter culture (control); SF133, SF138, and SF209 cheeses with single strain cultures of Lactobacillus helveticus SF133, SF138, or SF209, respectively; SF 133-138, SF 138-209, and SF 209-133 cheeses with two strain cultures; SF133-138-209: cheeses with three strain starter culture. Mean \pm standard deviation, $\mathrm{n}=3$.

\begin{tabular}{|c|c|c|c|c|c|c|c|c|c|}
\hline \multirow[b]{2}{*}{ Cheeses } & \multicolumn{3}{|c|}{$\mathrm{pH} 4.6 \mathrm{SN}$} & \multicolumn{3}{|c|}{ TCA SN } & \multicolumn{3}{|c|}{ PTA SN } \\
\hline & 0 & 90 & 180 & 0 & 90 & 180 & 0 & 90 & 180 \\
\hline $\mathrm{C}$ & $3.8^{\mathrm{a}} \pm 0.2$ & $12.9^{\mathrm{a}} \pm 0.8$ & $16.7^{\mathrm{a}} \pm 0.3$ & $1.2^{\mathrm{a}} \pm 0.1$ & $9.1^{\mathrm{a}} \pm 1.2$ & $13.3^{b c} \pm 1.2$ & $0.7^{\mathrm{a}} \pm 0.1$ & $4.0^{\mathrm{a}} \pm 1.3$ & $8.5^{\mathrm{ab}} \pm 0.8$ \\
\hline SF133 & $3.4^{\mathrm{a}} \pm 0.2$ & $12.2^{\mathrm{a}} \pm 1.1$ & $14.8^{\mathrm{a}} \pm 1.5$ & $1.3^{\mathrm{a}} \pm 0.6$ & $11.2^{\mathrm{a}} \pm 1.0$ & $13.4^{\mathrm{bc}} \pm 2.2$ & $0.8^{\mathrm{a}} \pm 0.3$ & $5.3^{\mathrm{a}} \pm 1.3$ & $7.2^{\mathrm{bc}} \pm 0.6$ \\
\hline SF 138 & $3.5^{\mathrm{a}} \pm 0.3$ & $13.0^{\mathrm{a}} \pm 1.2$ & $17.5^{\mathrm{a}} \pm 3.1$ & $1.3^{\mathrm{a}} \pm 0.1$ & $9.3^{\mathrm{a}} \pm 1.2$ & $11.6^{\mathrm{c}} \pm 2.1$ & $0.7^{\mathrm{a}} \pm 0.2$ & $4.6^{\mathrm{a}} \pm 0.3$ & $6.6^{\mathrm{bc}} \pm 0.8$ \\
\hline SF 209 & $3.6^{\mathrm{a}} \pm 0.3$ & $12.5^{\mathrm{a}} \pm 1.3$ & $17.4^{\mathrm{a}} \pm 1.7$ & $1.1^{\mathrm{a}} \pm 0.1$ & $10.7^{\mathrm{a}} \pm 1.1$ & $18.7^{\mathrm{a}} \pm 1.0$ & $0.7^{\mathrm{a}} \pm 0.1$ & $5.2^{\mathrm{a}} \pm 1.3$ & $10.5^{\mathrm{a}} \pm 1.3$ \\
\hline SF 209-133 & $3.8^{\mathrm{a}} \pm 0.4$ & $12.9^{\mathrm{a}} \pm 2.6$ & $17.4^{\mathrm{a}} \pm 4.9$ & $1.2^{\mathrm{a}} \pm 0.1$ & $10.3^{\mathrm{a}} \pm 0.7$ & $16.2^{\mathrm{ab}} \pm 2.0$ & $0.7^{\mathrm{a}} \pm 0.1$ & $4.6^{\mathrm{a}} \pm 0.3$ & $9.3^{\mathrm{ab}} \pm 2.3$ \\
\hline SF 133-138-209 & $3.2^{\mathrm{a}} \pm 0.4$ & $12.4^{\mathrm{a}} \pm 1.6$ & $19.2^{\mathrm{a}} \pm 4.5$ & $0.9^{\mathrm{a}} \pm 0.1$ & $11.6^{\mathrm{a}} \pm 2.3$ & $16.8^{\mathrm{ab}} \pm 1.6$ & $0.7^{\mathrm{a}} \pm 0.1$ & $5.5^{\mathrm{a}} \pm 1.4$ & $11.2^{\mathrm{a}} \pm 1.3$ \\
\hline
\end{tabular}

a,b,c Means within the same column without a common superscript $\operatorname{differ}(P<0.05)$.

with SF138 and SF133-SF138 starter cultures. The other cheeses showed intermediate values. Mediumsized to small peptides, amino acids, and smaller $\mathrm{N}$ compounds, such as amines/urea, and ammoniu (Ardö, 1999) are contained in TCA $12 \%$ SN.

On the other hand, soluble $\mathrm{N}$ in PTA $2.5 \%$ contains very small peptides, amino acids, and smaller $\mathrm{N}$ compounds other than dibasic amino acids and ammonia, which makes it a fair index of free amino acid content (Ardö, 1999). Similarly to TCA $12 \%$ SN, PTA $2.5 \%$ SN amount in cheeses prepared with different starter cultures did not differ during the first stage of ripening $(P$ $>0.05$ ), but it showed significant differences for 180-dold cheeses $(P<0.001)$. Means of PTA $2.5 \%$ SN were clustered in three homogeneous groups. Cheeses manufactured with SF209 in single or mixed cultures and control cheeses conformed one group, which showed the highest PTA 2.5\% SN level. An intermediate group of means was composed of cheeses manufactured with SF133, SF138, SF133-209, SF138-209, and control cheeses. On the other hand, cheeses prepared with SF133 and SF138 were also classed in a third group, along with SF133-SF138 culture; this group has the lowest PTA 2.5\% SN amount. The tendency detected by both TCA and PTA SN results was the same, which suggests that production of both medium to small peptides and free amino acids is encouraged when SF209 is in the starter.

Typical electrophoretic patterns for control and experimental 0-, 90-, and 180-d-old cheeses are shown in Figure 2. Control and experimental cheeses manufactured with single strain starters SF133 and SF138 are presented as examples. Electrophoretic profiles of cheeses made with SF209 and mixed starters were essentially the same (data not shown). Plasmin activity on $\beta$ casein, which leads to $\cdot \gamma$ caseins, was clearly observed.
Bands for $\gamma$ caseins increased from 0- to 90-d-old cheeses, while $\beta$ caseins band decreased accordingly. The $\gamma$ caseins were not more intense for 180- than for 90-d-old cheeses, even though $\beta$ casein band decreased, suggesting further degradations on $\gamma$ caseins. As expected, the $\alpha_{\mathrm{s} 2}$ casein disappeared in 90-d-old cheeses because this minor casein is, together with $\beta$ casein, one of the main substrates of plasmin (Grufferty and Fox, 1988). The $\alpha_{\mathrm{s} 1}$ casein was partially degraded to $\alpha_{\mathrm{s} 1}$-I peptide in 90- and 180-d-old cheeses. This breakdown has been attributed to residual chymosin or to cathepsin D in hard and Swiss-type cheeses (Delacroix Buchet and Fournier, 1992; Fox and McSweeney, 1996), but further research on the subject is probably needed. The similarity of all the electrophoretic patterns is consistent with the results of $\mathrm{NS}$ at $\mathrm{pH} 4.6$, which indicates that both markers are comparable for Reggianito Argentino cheese (Candioti et al., 2002).

All the chromatographic profiles of water-soluble extract of 0 -d-old cheeses were simple, with few large peaks, while chromatograms of 90- and 180-d-old cheeses showed more and larger peaks (Figure 3). Seventeen peaks were chosen by visually matching all the chromatograms and selecting the peaks whose areas varied most (Pripp et al., 1999). The selected peaks were identified with characters from $\boldsymbol{a}$ to $\boldsymbol{q}$ in alphabetical order (Figure 3). Areas of peaks $\boldsymbol{a}, \boldsymbol{b}, \boldsymbol{f}$, and $\boldsymbol{g}$ increased during ripening, while $\boldsymbol{c}, \boldsymbol{d}, \boldsymbol{j}, \boldsymbol{m}$, and $\mathbf{n}$ increased during the first $90 \mathrm{~d}$ but did not show further augmentation. The other peaks $(\boldsymbol{k}, \boldsymbol{l}, \boldsymbol{o}, \boldsymbol{p}, \boldsymbol{q})$ increased at the beginning of the ripening, then decreased. The changes on the peptide profile probably reflect the dynamic between peptide production and degradation to free amino acids and their metabolic products.

The three large peaks at the beginning of the chromatogram, identified as $\boldsymbol{a}, \boldsymbol{b}$, and $\boldsymbol{f}$, showed identical reten- 


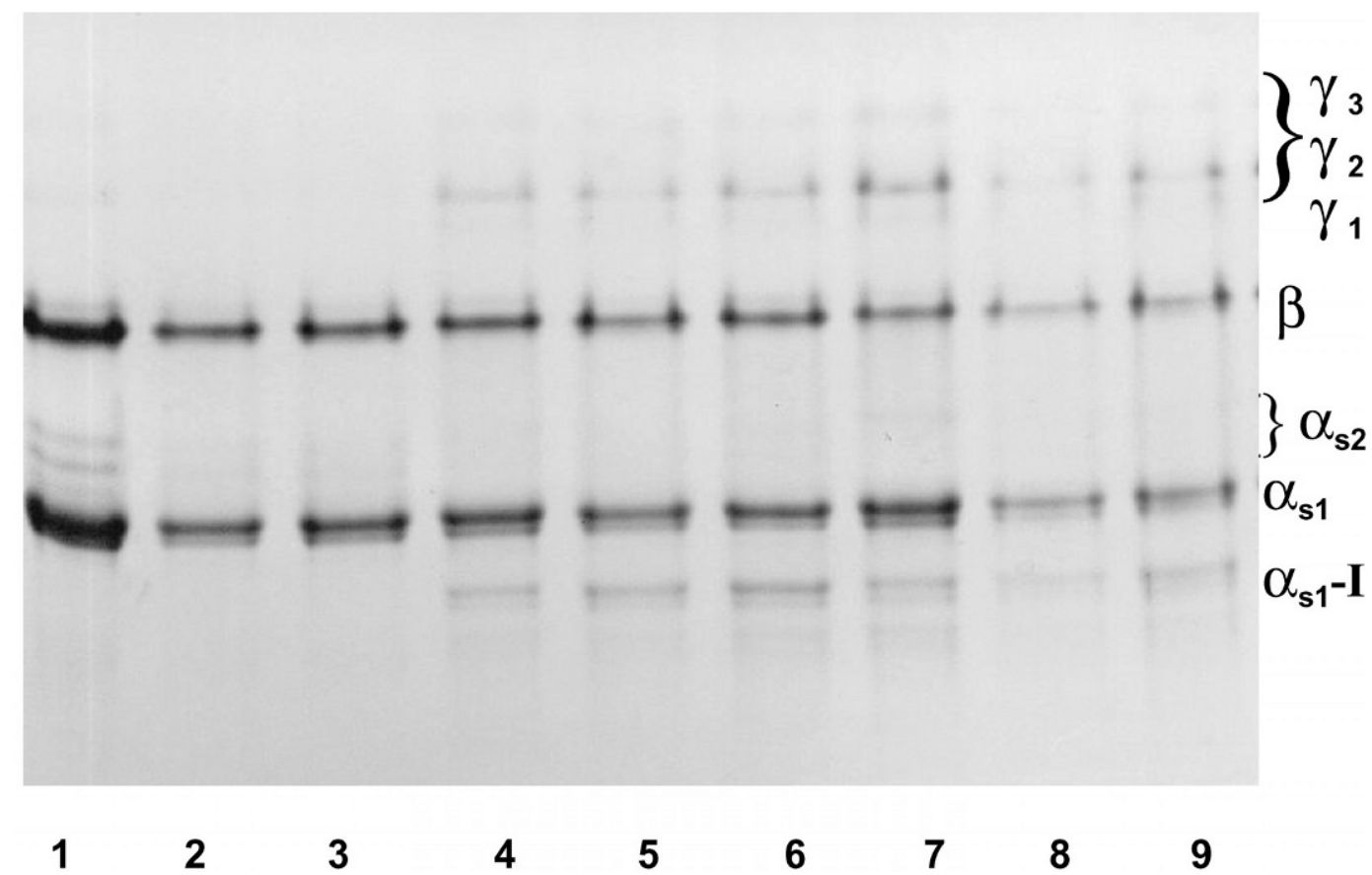

Figure 2. Urea polyacrylamide gel electrophoresis of 0-, 90- and 180-d-old Reggianito cheeses made with natural starter (control), or with single strain cultures of Lactobacillus helveticus SF133 or SF138. 1-3: control, SF133, and SF 138 cheeses at 0 d of ripening. 4-6: control, SF133, and SF 138 cheeses at 90 d of ripening 7-9: control, SF133 ,and SF 138 cheeses at $180 \mathrm{~d}$ of ripening.

tion time that hydrophobic amino acid Tyr, Phe, and Trp, respectively. They are similar to peaks found in Parmigiano Reggiano peptide profiles (Noël et al., 1998).

The areas of peaks $\boldsymbol{a}$ to $\boldsymbol{q}$ expressed on arbitrary units were considered as independent variables for PCA. We performed PCA with standardization of the variables to a mean of zero, and their original variances (covariance matrix) (Pripp et al., 2000). The first PC explained $94.92 \%$ of the variability, and was considered to retain most information existing in the original data taking into account two criteria: an eigenvalue $=1$ (the eigenvalue is defined as the column sum of squares for a PC that represents the amount of variance), and a scree plot, which is a plot of the eigenvalues or total variance accounted for by each component. The plot shows a distinct gap between the steepest slope of the large components and a progressive downward path (the scree) (Statgraphic plus 3.0). Even though one PC was enough to explain most of the variation, we retained the first two in order to obtain a two-dimension mapping for variables and samples, more readable than a onedimension plot or a table (Figure 4).

Loading vectors for the peaks are represented in Figure 4a. Peaks $\boldsymbol{a}, \boldsymbol{b}$, and $\boldsymbol{f}$ highly influenced PC1 equation, while peak $\boldsymbol{l}$ showed the highest loading for PC2. Differences among coefficient value and sign for $\mathbf{a}, \mathbf{b}$, f, and $\mathbf{l}$ could be explained taking into account that, while the first three peaks increased all along ripening, the last one increased during the first stage of maturation and then decreased (Figure 3).

The score plot is presented in Figure $4 \mathrm{~b}$. The scores on PC1 and PC2 for each sample, which represented mainly the production of amino acids Tyr, Phe, and Trp, were influenced by ripening time: 0 -d-old cheese show little variability, while 90 - and 180 -d-old cheeses were very variable. The samples were not clustered according to Lactobacillus strains or starter cultures of one, two, or three or more strains.

Taking into account the results of PCA, linear discriminant analysis (LDA) was applied to assess the age of the cheeses, using the first three PC as predictor variables (Figure 5) (Girard and Nakai, 1994; Santa María et al., 1986; Pham and Nakai, 1984). The 83.58\% of the samples were classified in the correct group, i.e., cheeses at the beginning, the middle, or the end of the ripening process. Some overlapping between 90 - and 180-d-old samples was observed, which caused the misclassification. As ripening is a continuum process, the groups may not be completely divided (Pham and Nakai, 1984)

Neither the strain of L. helveticus employed in the cheese-making nor the type of starter culture used (single, mixed, control) were accurately predicted by LDA; 


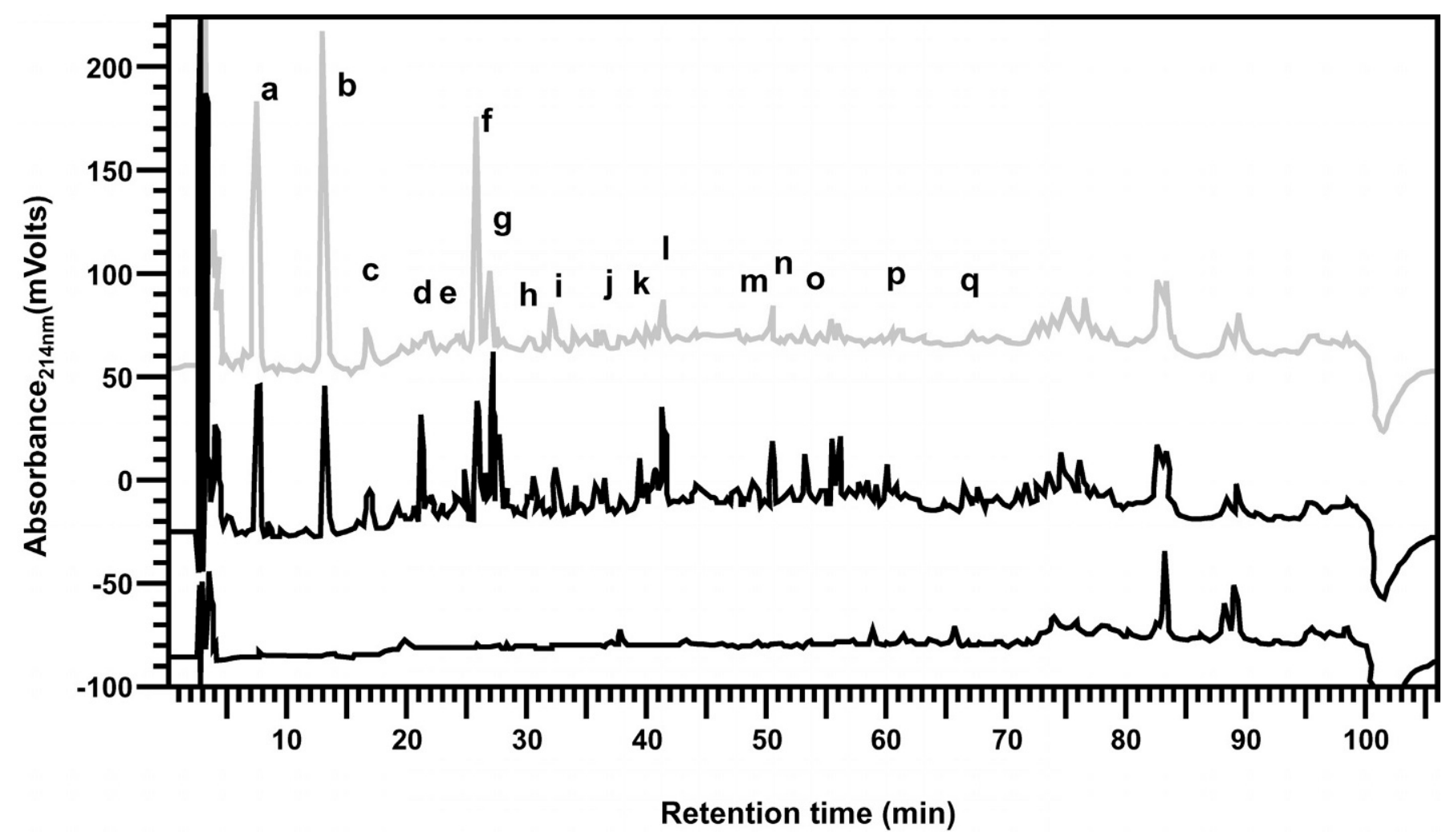

Figure 3. Reverse phase liquid chromatography profiles of water soluble extract of cheeses manufactured with a culture of Lactobacillus helveticus composed of the three selected strains SF133-138-209) at $0(\square), 90(-)$, and $180(-)$ d of ripening. Characters a to $\boldsymbol{q}$ point the peaks selected for principal component analysis.

although almost $50 \%$ of the samples were well classified, discriminant functions were not significant $(P>$ 0.05). This result was not surprising as relatively high variability was verified in the HPLC chromatograms of cheeses manufactured with the same starter culture.

\section{DISCUSSION}

Primary proteolysis was similar for all cheeses. Electrophoresis profiles and $\mathrm{SN}$ at $\mathrm{pH} 4.6$ did not significantly differ among cheeses prepared with different starter cultures. Lactobacillus helveticus ssp. have shown one of the strongest proteolytic activities among the lactic acid bacteria, and their cell wall proteinases are able to attack caseins $\alpha_{\mathrm{s}}$ and $\beta$ in vitro (Torriani et al., 1994; Mäyrä-Mäniken and Bigret, 1998); however, no evidence of such a breakdown was detected in the cheeses. Conversely, the influence of the starter culture on further hydrolysis of peptides was clearly evidenced by TCA $12 \%$ and PTA $2.5 \% \mathrm{SN}$, which contain relatively small $\mathrm{N}$ compounds. The differences indicated a stronger peptidase activity of the strain SF209 both in single culture or in mixed starters. This agrees with the fact that cheeses prepared with starter cultures containing SF209 showed the lowest counts of LAB at the end of the ripening, suggesting higher cell lysis and release of peptidases into the cheese mass. Nevertheless, we did not investigate bacterial lysis, so further research on this subject may be needed. The results on $\mathrm{N}$ fractions indicates that natural whey starter cultures could be replaced by several starters without significant changes on proteolysis patterns after $180 \mathrm{~d}$ of ripening. Starter cultures prepared only with SF209 or with the three selected L. helveticus strains, gave cheese products significantly more proteolyzed than control cheeses. As long as no defect was detected in cheeses made with SF209 and SF133-SF138-SF209 starter cultures, those could be selected in order to obtain products characterized by a more intense proteolysis, and, therefore, potentially enhanced flavor and texture. On the contrary, starters composed of SF133-SF138 seem not to be so attractive, since cheeses made with them showed the lowest level of proteolysis. However, the fact that proteolysis is not the limiting step in cheese flavor production should not be disregarded when starter selection is attempted. In effect, Yvon and Rij- 

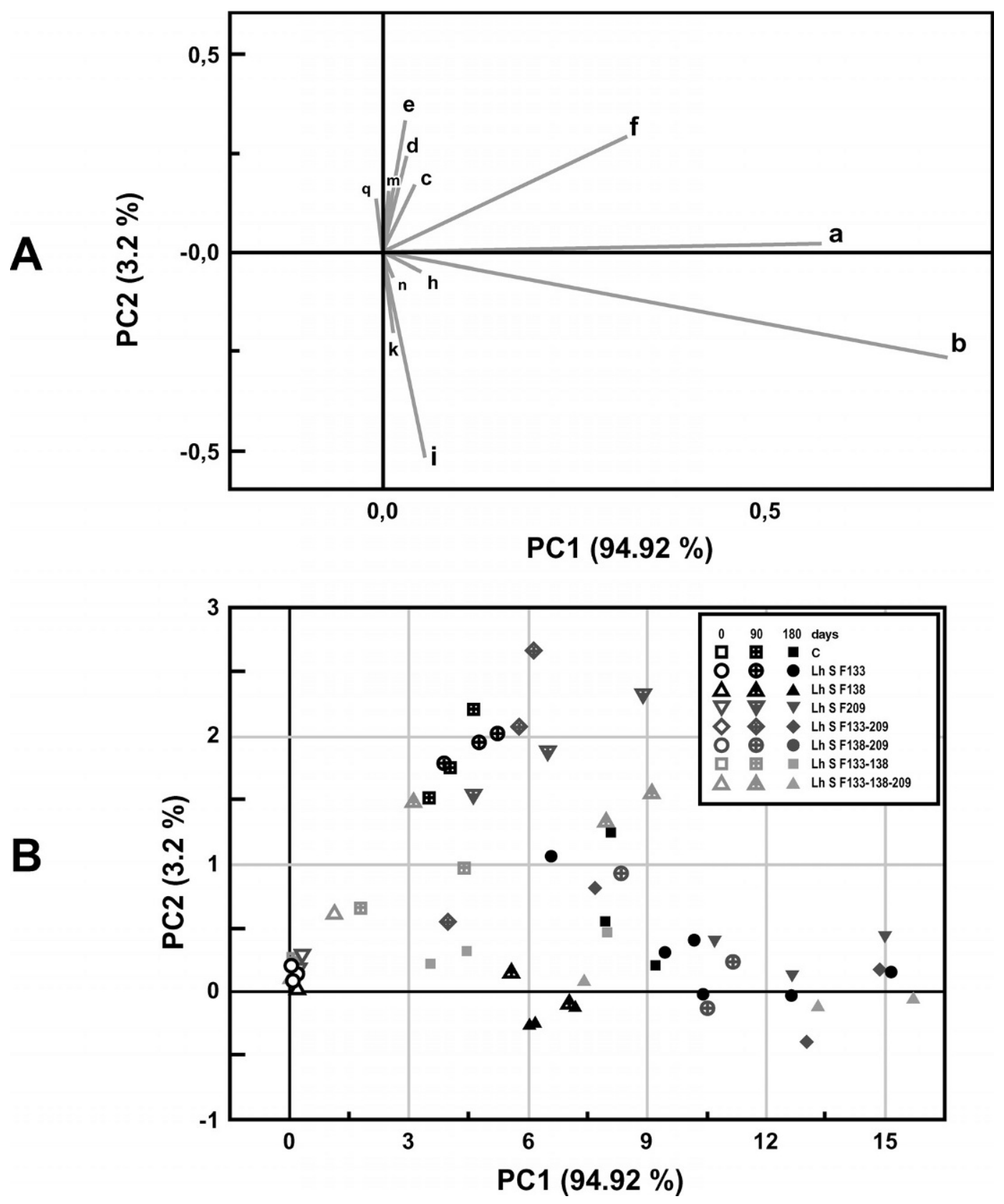

Figure 4. Principal component (PC) analysis of chromatographic profiles. A) Loadings of the independent variables (area of peaks $\boldsymbol{a}$ to $\boldsymbol{q}$ on the chromatograms) on PC1 and PC2. Peaks with the highest loadings are identified with the characters $(\boldsymbol{a}, \boldsymbol{b}, \boldsymbol{f}, \boldsymbol{l})$; peaks with intermediate loadings are shown with characters $(\boldsymbol{e}, \boldsymbol{d}, \boldsymbol{c}, \boldsymbol{k}, \boldsymbol{h}, \boldsymbol{m}, \boldsymbol{n}, \boldsymbol{q})$, while peaks with minor loadings are not labeled $(\boldsymbol{g}, \boldsymbol{i}, \boldsymbol{j}, \boldsymbol{o}, \boldsymbol{p})$. B) Score plot of 0, 90, and 180 d-old-cheese samples on PC1 and PC2. C: cheese prepared with "natural" whey starter. SF133, SF138, and SF209: cheeses prepared with single strain cultures of Lactobacillus helveticus; SF 133-138, SF 138-209, and SF 209-133: cheeses with two strain cultures; SF133-138-209: cheeses with three-strain starter culture.

nen (2001) have shown that the conversion of free amino acids into flavor-related compounds via a transaminase-catalized reaction is a key event in the production of cheese flavor and is not necessarily increased by increased proteolysis. Sensory analysis or volatile compounds assessment are therefore suitable techniques to provide complimentary information (Candioti et al., 2002).

Multivariate analysis of chromatographic profiles revealed that samples did not cluster by Lactobacillus strain or type of starter (single, mixed, or natural cultures), because intra- and intergroup variability was 


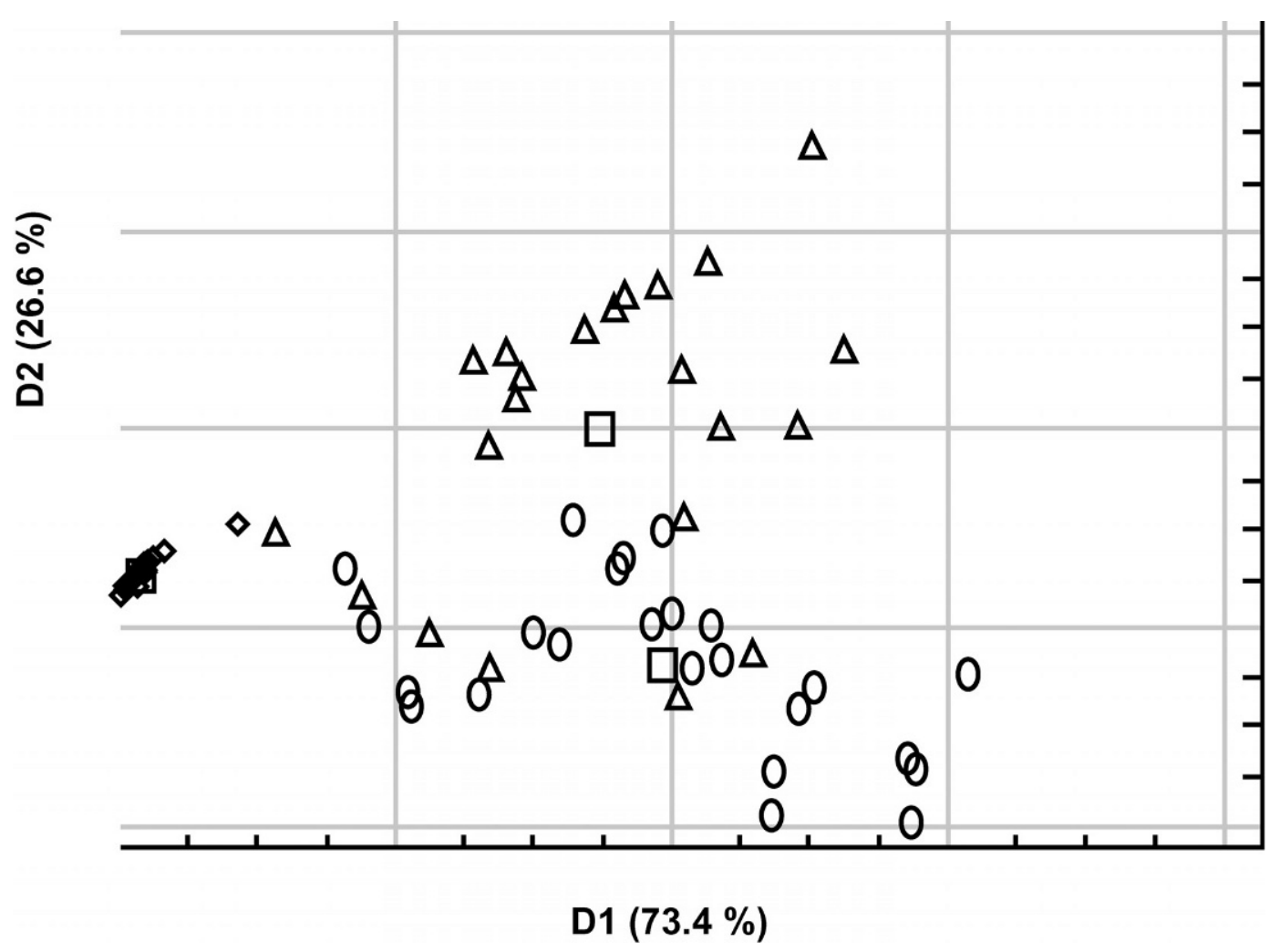

Figure 5. Linear discriminant functions (D1 and D2) for cheese samples at 0, 90, and $180 \mathrm{~d}$ of ripening. 0 0-day-old cheeses $\boldsymbol{\Delta}$ 90-d-oldcheeses $\bigcirc$ 180-d-old cheeses $\square$ Group centroids.

similar. On the other hand, multivariate techniques were successful in classifying samples by the stage of ripening. Thus, variability among samples was explained mainly by the time of ripening, which appears as a key technological parameter to obtain Reggianito cheese products with similar proteolysis characteristics and therefore a constant quality level.

The fact that the initial cleavage of caseins was very similar for all cheeses, while secondary proteolysis indexes evidenced significant differences among them, along with the importance of the peaks identified as Phe, Trp, and Tyr in peptide profiles, suggests that free amino acids profiling may be a more useful technique than peptide mapping to characterize the role of $L$. helveticus starters. In further studies we will focus on the setting up of this technique in our laboratory.

We conclude that the replacement of natural whey starter cultures by selected strains cultured in whey is possible without changes in the proteolysis patterns of Reggianito Argentino cheese.

\section{ACKNOWLEDGMENTS}

Funding for this study was provided by the grant PICT98 09-04631, from ANPCYT (Agencia Nacional de
Promoción Científica y Tecnológica), Argentina. The authors wish to thank Ms. Sc. Mario Candioti and B.Sc. Susana Palma for their technical assistance in cheese making and $\mathrm{N}$ fraction analysis, respectively.

\section{REFERENCES}

Andrews, A. T. 1983. Proteinases in normal bovine milk and their action on caseins. J. Dairy Res. 50:45-55.

Annibaldi, S. 1969. Modificazione della prova di Weinzil per la ricerca dei clostridi butirrici nel latte. Sci. Tec. Lat. Cas. 20:75-79.

Ardö, Y. 1999. Evaluating proteolysis by analysing the $\mathrm{N}$ content of cheese fraction. Pages 4-9 in Chemical Methods for Evaluating proteolysis in Cheese Maturation, Part 2, Bulletin of the IDF 337. Brussels, Belgium.

Bosi, F., M. Vescovo, V. Bottazzi, G. L. Scolari, B. Battistotti, and E. Brambilla. 1991. Batteri lattici per la produzione di formaggio Grana. II Integrazione di siero-fermento naturale con colture pure di bacilli lattici termofilli. Sci. Tec. Lat. Cas. 42:171-179.

Bottazzi, V., M. G. Parisi, and P. S. Cocconcelli. 1999. Colture di batteri lattici per la produzione di formaggio grana e tipizzazione molecolari dei ceppi. Sci. Tec. Lat. Cas. 50:179-194.

Bottazzi, V., G. L. Scolari, F. Cappa, B. Battistotti, F. Bosi, and E. Brambilla. 1992. Batteri lattici per la produzione di formaggio Grana. III. Velocità di acidificazione e comparsa di gonfiore. Sci. Tec. Lat. Cas. 43:71-93.

Bradley, R. L., E. Arnold, D. M. Barbano, R. G. Semerad, D. E. Smith, and B. K. Vines. 1993. Chemical and physical methods. Pages 433-531 in Standard methods for the examination of Dairy Products. R. T. Marshall, ed. Am. Publ. Health Assoc., Inc., Washington, DC. 
Candioti, M. C., E. R. Hynes, A. Quiberoni, S. B. Palma, N. Sabbag, and C. A. Zalazar. 2002. Reggianito Argentino cheese: Influence of Lactobacillus helveticus strains isolated from natural whey cultures on cheese making and ripening processes. Int. Dairy J. 12:923-931.

Centro de la Industria Lechera. 2001. Reseña estadística. Online. Available: http://www.cil.org.ar.

Choisy, C., M. Desmazeaud, J. C. Gripon, G. Lamberet, and J. Lenoir. 1997. La Biochimie de l'affinage. Pages $86-16$ in Le Fromage. A. Eck and J.C. Gillis, ed. Lavoisier, Paris, France.

Christen, G. L., P. M. Davidson, J. S. McAllister, and L. A. Roth. 1993. Coliform and other indicator bacteria. Pages 247-269 in Standard methods for the examination of Dairy Products. R. T. Marshall, ed. Am. Publ. Health Assoc., Inc., Washington D.C.

Código Alimentario Argentino. 1999. De La Canal y Asociados. Buenos Aires, Argentina.

Crow, V. L., T. Coolbear, R. Holland, G. Pritchard, and F. Martley. 1993. Starters as finishers: starter properties relevant to cheese ripening. Int. Dairy J. 3:423-460.

Delacroix-Buchet, A., and S. Fournier. 1992. Protéolyse et texture des fromages à pâte cuite pressée. II. Influence de la chymosine et des conditions de fabrication. Lait 72:53-72.

Fox, P. F., and P. L. H. McSweeney. 1996. Proteolysis in cheese during ripening. Food Rev. Int. 12:457-509.

Frank, J., G. Christen, and L. Bullerman. 1993. Test for groups of microorganism. Pages 271-286 in Standard methods for the examination of Dairy Products. R. T. Marshall ed. Am. Publ. Health Assoc., Inc., Washington DC.

Gallino, R. 1994. Queso Reggianito Argentino: tecnología de fabricación. Pages 244-287 in Tecnología de los Productos Lácteos. Diagramma S. A. Santa Fe, Argentina.

Giraffa, G., G. Mucchetti, F. Addeo, and E. Neviani, E. 1997. Evolution of lactic acid microflora during Grana cheesemaking and ripening. Microbiol. Aliments Nutr. 15:115-122.

Giraffa, G., L. Rossetti, G. Mucchetti, F. Addeo, and E. Neviani. 1998. Influence of the temperature gradient on the growth of themophilic lactobacilli used as natural starters in Grana cheese. J. Dairy Sci. 81:31-36.

Girard, B., and S. Nakai S. 1994. Grade classification of canned pink salmon with static headspace volatile patterns. J. Food Sci. 59:507-512.

Gripon, J. C., M. J. Desmazeaud, D. Le Bars, and J. L. Bergère. 1975. Étude du rôle des micro organismes et des enzymes au cours de la maturation du fromage. II Influence de la présure commérciale. Lait 55:502-516.

Grufferty, M. B., and P. F. Fox. 1988. Milk alkaline proteinase. J. Dairy Res. 55:609-630.

Hynes, E., A. Delacroix-Buchet, C. A. Meinardi, and C. A. Zalazar. 1999. Relation between $\mathrm{pH}$, degree of proteolysis and consistency in soft cheese. Aust. J. Dairy Technol. 54:24-27.

Hynes, E., C. A. Meinardi, N. Sabbag, T. Cattaneo, M. C. Candioti, and C. A. Zalazar. 2001. Influence of milk-clotting enzyme concentration on the $\alpha_{\mathrm{s} 1}$ casein hydrolysis during soft cheeses ripening. J. Dairy Sci. 84:1335-1340.
International Dairy Federation. 1962. Formaggio e formaggio fuso. Determinazione della materia secca. Metodo di riferimento. No. 4:A. IDF, Brussels, Belgium.

International Dairy Federation. 1993. Latte. Determinazione del tenore in azoto. Metodo di riferimento. No. 20:B. IDF, Brussels, Belgium.

Mäyrä-Mäniken, A., and M. Bigret. 1998. Industrial use and production of lactic acid bacteria. Pages 73-102 in Lactic acid bacteria microbiology and functional aspects. S. Salimen and A. von Wright, eds. Marcel Dekker, Inc., New York, NY.

McSweeney, P. L. H., and M. J. Sousa. 2000. Biochemical pathways for the production of flavor compounds in cheeses during ripening: a review. Lait 80:293-324.

Noël, Y., Y. Ardö, S. Pochet, A. Hunter, P. Lavanchy, W. Luginbühl W., D. Le Bars, A. Polychoniadou, and L. Pellegrino. 1998. Characterization of protected denomination of origin cheeses: relationships between sensory texture and instrumental data. Lait 78:569-588.

Paleari, M. A., G. Soncini, G. Beretta, and M. Aldrighi. 1996. Autochthonous lactic acid bacteria used as starter cultures in making of a typical cheese. Microbiol. Aliments Nutr. 14:357-362.

Pham, A. M., and S. Nakai. 1984. Application of stepwise discriminant analysis to high pressure liquid chromatography profiles of water extract for judging ripening of Cheddar cheese. J. Dairy Sci. 67:1390-1396.

Pripp, A. H., L. Stepaniak, T. Sørhaug. 2000. Chemometrical analysis of proteolytic profiles during cheese ripening. Int. Dairy J. 10:249-253.

Quiberoni, A., M. C. Candioti, C. A. Meinardi, S. Palma, and J. Reinheimer. 1997. Selección y utilización de mutantes espontáneos fagorresistentes de Lactobacillus helveticus en quesería. Rev. Argentina Lactología 15:13-34.

Quiberoni, A., P. Tailliez, P. Quénee, V. Suárez, and J. Reinheimer. 1998. Genetic (RAPD-PCR) and technological diversities among wild Lactobacillus helveticus strains. J. Appl. Microbiol. 85:591-596.

Reinheimer, J., A. Quiberoni, P. Tailliez, A. Binetti, and V. Suárez. 1996. The lactic acid microflora of natural whey starters used in Argentina on hard cheese production. Int. Dairy J. 6:869-879.

Reinheimer, J., V. Suárez, N. Bailo, and C. A. Zalazar. 1995. Microbiological and technological characteristics of natural whey cultures for Argentinean hard cheese production. J. Food Prot. 54:796-799.

Santa María, G., M. Ramos, J. A. Ordóñez. 1986. Application of Linear Discriminant Analysis to Different Proteolysis Parameters for Assessing the Ripening of Manchego Cheese. Food Chem. 19:225-234.

Torriani, S., M. Vescovo, and G. Scolari. 1994. An overview on Lactobacillus helveticus. Ann. Microbiol. Enzymol. 44:163-191.

Yvon, M., and L. Rijnen (2001) Cheese flavour formation by amino acid catabolism. Int. Dairy J. 11:185-201.

Zalazar, C. A., C. A. Meinardi, and E. R. Hynes. 1999. Quesos típicos argentinos. Producción y características. Una revisión. Centro de Publicaciones de la Universidad Nacional del Litoral, Santa Fe, Argentina. 